\title{
Hydrilla verticillata-Sulfur-Based Heterotrophic and Autotrophic Denitrification Process for Nitrate-Rich Agricultural Runoff Treatment
}

\author{
Qianyu Hang ${ }^{1,2}$, Haiyan Wang ${ }^{1,2, * \mathbb{D}}$, Zan He ${ }^{1,3}$, Weiyang Dong ${ }^{1,2}$, Zhaosheng Chu ${ }^{1,4, *}$, \\ Yu Ling ${ }^{1,2}$, Guokai Yan ${ }^{1,2}$, Yang Chang ${ }^{1,2}$ and Congyu $\mathrm{Li}^{1,2}$ \\ 1 State Key Laboratory of Environmental Criteria and Risk Assessment, Chinese Research Academy of \\ Environmental Sciences, No. 8 Da Yang Fang, Anwai, Chaoyang District, Beijing 100012, China; \\ qhang@ncsu.edu (Q.H.); hezan1203@163.com (Z.H.); docreat@163.com (W.D.); \\ lingyu18@mails.ucas.ac.cn (Y.L.); yangk@craes.org.cn (G.Y.); cy1100@126.com (Y.C.); \\ licongyu1996@163.com (C.L.) \\ 2 Engineering Center for Environmental Pollution Control, Chinese Research Academy of Environmental \\ Sciences, Beijing 100012, China \\ 3 Beijing China's Sustainable Development Water Purification Material Technology Co., Beijing 100012, China \\ 4 National Engineering Laboratory for Lake Pollution Control and Ecological Restoration, Chinese Research \\ Academy of Environmental Sciences, No. 8 Da Yang Fang, Anwai, Chaoyang District, Beijing 100012, China \\ * Correspondence: wanghy@craes.org.cn (H.W.); chuzs@craes.org.cn (Z.C.); Tel.: +86-10-8491-5322 (H.W.); \\ +86-10-8491-5317 (Z.C.); Fax: +86-10-8491-5923 (H.W.); +86-10-8491-5317 (Z.C.)
}

Received: 4 January 2020; Accepted: 25 February 2020; Published: 29 February 2020

check for updates

\begin{abstract}
Hydrilla verticillata-sulfur-based heterotrophic and autotrophic denitrification (HSHAD) process was developed in free water surface constructed wetland mesocosms for the treatment of nitrate-rich agricultural runoff with low chemical oxygen demand/total nitrogen $(C / N)$ ratio, whose feasibility and mechanism were extensively studied and compared with those of $H$. verticillata heterotrophic denitrification (HHD) mesocosms through a 273-day operation. The results showed that the heterotrophic and autotrophic denitrification can be combined successfully in HSHAD mesocosms, and achieve satisfactory nitrate removal performance. The average $\mathrm{NO}_{3}{ }^{-}-\mathrm{N}$ removal efficiency and denitrification rate of $\mathrm{HSHAD}$ were $94.4 \%$ and $1.3 \mathrm{~g} \mathrm{NO}_{3}{ }^{-}-\mathrm{N} \mathrm{m}^{-3} \cdot \mathrm{d}^{-1}$ in steady phase II (7-118 d). Most nitrate was reduced by heterotrophic denitrification with sufficient organic carbon in phase I (0-6 d) and II, i.e., the $\mathrm{C} / \mathrm{N}$ ratio exceeded 4.0, and no significant difference of nitrate removal capacity was observed between HSHAD and HHD mesocosms. During phase III (119-273 d), sulfur autotrophic denitrification gradually dominated the HSHAD process with the $\mathrm{C} / \mathrm{N}$ ratio less than 4.0, and HSHAD mesocosms obtained higher $\mathrm{NO}_{3}{ }^{-}-\mathrm{N}$ removal efficiency and denitrification rate $\left(79.1 \%\right.$ and $\left.1.1 \mathrm{~g} \mathrm{NO}_{3}{ }^{-}-\mathrm{N} \mathrm{m}^{-3} \cdot \mathrm{d}^{-1}\right)$ than HHD mesocosms $\left(65.3 \%\right.$ and $\left.1.0 \mathrm{~g} \mathrm{NO}_{3}{ }^{-}-\mathrm{N} \mathrm{m}^{-3} \cdot \mathrm{d}^{-1}\right)$. As a whole, HSHAD mesocosms removed $58.8 \mathrm{mg} \mathrm{NO}_{3}{ }^{-}-\mathrm{N}$ more than HHD mesocosms. $\mathrm{pH}$ fluctuated between 6.9-9.0 without any $\mathrm{pH}$ buffer. In general, HSHAD mesocosms were more stable and efficient than $\mathrm{HHD}$ mesocosms for $\mathrm{NO}_{3}{ }^{-}-\mathrm{N}$ removal from agricultural runoff during long-term operation. The denitrificans containing narG $\left(1.67 \times 10^{8} \pm 1.28 \times 10^{7}\right.$ copies g $^{-1}$ mixture-soil $\left.^{-1}\right)$, nirS $\left(8.25 \times 10^{7}\right.$ $\pm 8.95 \times 10^{6}$ copies g $^{-1}$ mixture-soil $\left.{ }^{-1}\right)$, and nos $\left(1.56 \times 10^{6} \pm 1.60 \times 10^{5}\right.$ copies g $^{-1}$ mixture-soil $\left.^{-1}\right)$ of litter bags and bottoms in HSHAD were higher than those in HHD, which indicated that the combined heterotrophic and autotrophic denitrification can increase the abundance of denitrificans containing narG, nirS, and nosZ, thus leading to better denitrification performance.
\end{abstract}

Keywords: Hydrilla verticillata; carbon source; heterotrophic denitrification; sulfur autotrophic denitrification; agricultural runoff; constructed wetland mesocosms 


\section{Introduction}

Agricultural runoff always has high nitrate and low chemical oxygen demand (COD)/total nitrogen $(\mathrm{TN})(\mathrm{C} / \mathrm{N})$ ratio. Increased nitrate availability in agricultural runoff may lead to serious eutrophication and deterioration of public health in many cases [1-3]. Among the available approaches, the free water surface constructed wetland has recently been identified as an effective and ecologically sustainable technology for the treatment of agricultural runoff $[4,5]$.

Biological denitrification, occurring either heterotrophically or autotrophically, accounts for $60-90 \%$ of the total nitrate reduction [6-8]. Among popular electron donors for autotrophic denitrification, sulfur has competitive characteristics of cost-effectiveness, nontoxicity, water-insolubility, and wide availability $[9,10]$. In the heterotrophic denitrification process, some chemical organics such as methanol and glucose are widely used as additional carbon sources for the treatment of nitrate-contaminated wastewater with a low $\mathrm{C} / \mathrm{N}$ ratio [11]. However, such methods are costly due to the continuous organics dosage [12]. What is more, the residual chemical organics added need to be further treated. To substitute the chemical organics and reduce costs, various plant biomass has been proved to be feasible for the improvement of heterotrophic denitrification efficiency [13-16].

Previous studies have obtained favorable denitrification performance by applying combined heterotrophic and autotrophic denitrification (HAD) process in the treatment of drinking water [17-19], hydroponic wastewater [20], groundwater [21,22], simulated wastewater [23-31], etc. A woodchip-sulfur combined mixotrophic process was recently developed to eliminate nitrate from groundwater [31], whose denitrification performance was better than that of the sulfur-based autotrophic denitrification systems. However, it was only operated in serum bottles for less than two weeks with limited experimental data. Another study discussed the effects of coexistent ions including $\mathrm{Na}^{+}, \mathrm{Cl}^{-}, \mathrm{HCO}_{3}{ }^{-}, \mathrm{Ca}^{2+}, \mathrm{Cu}^{2+}, \mathrm{Fe}^{2+}, \mathrm{Fe}^{3+}, \mathrm{HCO}_{3}{ }^{-}$, and $\mathrm{SO}_{4}{ }^{2-}$ on nitrate removal by combined sawdust-based heterotrophic and Fe-based autotrophic denitrification processes [23]. Further investigation is needed to prove that HAD process works better than individual heterotrophic denitrification for the improvement of nitrate removal capacity during long-term operation.

Dissolved organic matter (DOM), which is one of the important components in organic compounds of plant biomass, is a key influencing factor for heterotrophic denitrification performance [32]. Recent studies have demonstrated that parallel factor analysis (PARAFAC) could decompose full excitation-emission matrix (EEM) fluorescence into different independent fluorescent groups [33], and it is a valuable tool for the characterization and quantification of DOM fluorescence changes.

Based on the studies mentioned above, the Hydrilla verticillata (H. verticillata)—sulfur-based heterotrophic and autotrophic denitrification (HSHAD) process was put forward. H. verticillata is a fresh-water aquatic plant used as the carbon source. This paper aims to verify the feasibility and mechanism of the HSHAD process for the treatment of high nitrate and low $\mathrm{C} / \mathrm{N}$ ratio agricultural runoff in free water surface constructed wetland mesocosms during long-term operation. Characteristics of $H$. verticillata decomposition and denitrification performance in the HSHAD mesocosms were also extensively studied in long-term operation and compared with those in $H$. verticillata-based heterotrophic denitrification (HHD) mesocosms. DOM changes were also analyzed to elaborate the HSHAD mechanism.

\section{Materials and Methods}

\subsection{Source of Material and Pretreatment}

Lake Erhai is a typical plateau lake in Dali city, Yunnan Province, Southwest China. H. verticillata and soil samples were collected from the water near the shore and the paddy-field along the littoral zone of Lake Erhai $\left(25^{\circ} 36^{\prime}-25^{\circ} 58^{\prime} \mathrm{N}, 100^{\circ} 06^{\prime}-100^{\circ} 18^{\prime} \mathrm{E}\right)$, respectively, in August 2014. H. verticillata samples were cleaned, cut into 1 to $2 \mathrm{~cm}$ pieces and oven-dried at $40^{\circ} \mathrm{C}$ to constant weight. Soil samples were air-dried to constant weight, milled and screened through 100-mesh sieve. The granular sulfur (1-2 cm, $>99.9 \%)$ and pebbles $\left(\mathrm{SiO}_{2}, 1-2 \mathrm{~cm}\right)$ were bought from local companies. 


\subsection{Mesocosm Set-Up and Operation}

Six $5 \mathrm{~L}$ laboratory-scale, free water surface constructed wetland mesocosms were made using plastic buckets $(0.17 \mathrm{~m}$ bottom inner diameter, $0.23 \mathrm{~m}$ upper inner diameter, $0.21 \mathrm{~m}$ height) and fed with $2.0 \mathrm{~L}$ synthetic agricultural runoff. Pretreated soil from Lake Erhai shore and paddy-field were mixed homogeneously at a 1:1 mass ratio, and then added into the mesocosms. The litter bag technique could carry out the decomposition and denitrification experiments [34-36]. A litter bag (0.16 m length, $0.12 \mathrm{~m}$ width) loaded with different media (Table 1 ) was placed on the bottom soil (Table 1 ) surface in each mesocosm, and the litter bag was made of nylon with approximately $1.0 \mathrm{~mm}$ mesh. Two HSHAD mesocosms (packed with $H$. verticillata and sulfur in the litter bag), two HHD mesocosms (packed with only H. verticillata in the litter bag), and two control mesocosms (packed with only soil and gravels in the litter bag) (Table 1) were used. The schematic diagram of the mesocosm was published in a previous study [26].

Table 1. Details of experimental set-up.

\begin{tabular}{|c|c|c|c|c|c|c|c|}
\hline Mesocosm & Plant & \multicolumn{4}{|c|}{ Mass Composition in Litter Bags $(\mathrm{g}) *$} & $\begin{array}{l}\text { Bottom Soil } \\
\text { Layer }(\mathrm{g}) *\end{array}$ & $\begin{array}{c}\text { Simulated } \\
\text { Wastewater }(\mathrm{L}) \text { * }\end{array}$ \\
\hline HSHAD & H. verticillata & 10.0 & 1.9 & 42.9 & 28.6 & 57.1 & 2.0 \\
\hline HHD & H. verticillata & 10.0 & 0 & 42.9 & 28.6 & 57.1 & 2.0 \\
\hline Control & - & 0 & 0 & 42.9 & 28.6 & 57.1 & 2.0 \\
\hline
\end{tabular}

* The values were taken from the duplicate samples. ${ }^{* *}$ The gravel was used to sink the litter bags into the surface of bottom soil layer. HSHAD (Hydrilla verticillata-sulfur-based heterotrophic and autotrophic denitrification, HHD (H. verticillata heterotrophic denitrification).

Based upon one-year monitored data of the agricultural runoff in the Lake Erhai area, the ingredients of the simulated agricultural runoff were $0.5 \mathrm{mg} \mathrm{L}^{-1} \mathrm{NH}_{4}{ }^{+}-\mathrm{N}, 7.4 \mathrm{mg} \mathrm{L}^{-1} \mathrm{NO}_{3}{ }^{-}-\mathrm{N}$, $1.2 \mathrm{mg} \mathrm{L}^{-1} \mathrm{NO}_{2}{ }^{-}-\mathrm{N}, 9.1 \mathrm{mg} \mathrm{L}^{-1} \mathrm{TN}, 1.2 \mathrm{mg} \mathrm{L}^{-1} \mathrm{TP}$, and $3.2 \mathrm{mg} \mathrm{L}^{-1} \mathrm{COD}$, which were achieved by the addition of $1.457 \mathrm{~g} \mathrm{NaNO}_{3}, 0.057 \mathrm{~g} \mathrm{NaNO}_{2}, 0.023 \mathrm{~g} \mathrm{NH}_{4} \mathrm{Cl}, 0.241 \mathrm{~g} \mathrm{KH}_{2} \mathrm{PO}_{4}$, and 0.419 g glucose into tap water. The $\mathrm{pH}$ was 8.3. The experiment was conducted in static mode by intermittent dosage of $\mathrm{NaNO}_{3}$ supporting denitrificans growth at constant $\mathrm{NO}_{3}{ }^{-}-\mathrm{N}$ concentration $\left(7.4 \mathrm{mg} \mathrm{L}^{-1}\right)$ for 273 days, i.e., from 14 January to 14 October 2015 . The temperature was kept at 19 to $25^{\circ} \mathrm{C}$ using air conditioner. Since the nitrate concentration in the control mesocosms was too high $\left(126.1 \mathrm{mg} \mathrm{L}^{-1}\right)$, the water column of all mesocosms was replaced by the simulated agricultural runoff on the 204th day.

\subsection{Sampling and Analytical Procedure}

To avoid agitation of the bottom soil, water was sampled from the top using a $50 \mathrm{~mL}$ syringe. Meanwhile, the same volume of deionized water was injected into the mesocosms for compensation. At the beginning and end of the experiments, cellulose, hemicellulose, and lignin contents of $H$. verticillata were quantified according to Van Soest's method [7]. Organic carbon was analyzed by the potassium dichromate oxidation-external heating method (LY/T 1237-1999) [37]. TN was determined by automatic azotometer (UK152 Distillation and Titration Unit, Velp Co., Milano, Italy). TP was determined by inductively coupled plasma-atomic emission spectrometry (IRIS Intrepid II XSP, Thermo, Waltham, MA, USA). Before analysis, $H$. verticillata pieces were cleaned, oven-dried at $40{ }^{\circ} \mathrm{C}$ to constant weight, and then milled and screened through 60-mesh sieve.

$\mathrm{NH}_{4}{ }^{+}-\mathrm{N}$ and TP were determined by standard methods [38]. $\mathrm{NO}_{3}{ }^{-}-\mathrm{N}$ and $\mathrm{NO}_{2}{ }^{-}-\mathrm{N}$ were analyzed by ion chromatography (DIONEX ICS-1000, Dionex Inc., Sunnyvale, CA, USA) after $0.45 \mu \mathrm{m}$ syringe tip-filter filtration (SCAA-201). COD was measured with a COD rapid testing instrument (model TCL-12, Hebei Chengde Huatong Environmental Instrument Ltd. Co., Chengde, China). pH was analyzed with S-25 pH Analyzer (Shanghai Precision and Scientific Instrument Ltd. Co., Shanghai, China).

DOM in water samples was characterized by three-dimensional EEM fluorescence spectrophotometer (Hitachi F-7000 Fluorescence Spectrophotometer, Japan) after glass microfiber 
filtration (Whatman GF/C glass microfiber filters). A xenon excitation source was used for the spectrometer. Both the excitation (Ex) and emission (Em) were 200-500 nm with $5 \mathrm{~nm}$ bandwidth, and the scanning speed was $12,000 \mathrm{~nm} / \mathrm{min}$. Milli-Q water was utilized as blank control. Fluorescence spectroscopy coupled with parallel factor analysis (PARAFAC) was applied in DOM fluorescence characterization.

\subsection{DNA Extraction and Q-PCR}

Mixed soil from the bucket bottom, and mixture (gravel/H. verticillata pieces/mixed soil) from litter bags were collected on the 273th day for denitrificans genes analysis using quantitative polymerase chain reaction (q-PCR) method.

Before deoxyribonucleic acid (DNA) extraction, the mixture from litter bags was shaken at $200 \mathrm{r}$ $\mathrm{min}^{-1}$ for $1 \mathrm{~h}$ in sterile glass bottles in order to detach the biofilm into a liquid phase. Total genomic DNA was extracted using the E.Z.N.A ${ }^{\circledR}$ Soil DNA Kit (OMEGA bio-tek, Doraville, GA, USA), and was subject to q-PCR assays targeting the narG, nirS, and nosZ genes.

Primers were selected for the amplification of narG (forward primer, $1960 \mathrm{~m} 2 \mathrm{f}$ : TA(CT)GT(GC)GGGCAGGA(AG)AAA; reverse primer, 2050 m2r: CGTAGAAGAAGCTGGTGCTG TT) [39], nirS (forward primer, cd3af: GTSAACGTSAAGGARACSGG; reverse primer, R3cd: GASTTCGGRTGSGTCTTGA) [40], and nosZ (forward primer, F:CG(C/T)TGTTC(A/C)TCGACAGC CAG; reverse primer, 1622R: CG(G/C)ACCTT(G/C)TTGCC(C/G)T(T/C)GCG) [41]. The q-PCR assays were performed on ABI 7500 fast real time PCR platform (Life Technologies, Carlsbad, CA, USA) using SYBR-green based detection. Q-PCR was conducted using a two-step amplification procedure under following conditions: $95^{\circ} \mathrm{C}$ for $10 \mathrm{~min}, 40$ cycles of $95^{\circ} \mathrm{C}$ for $15 \mathrm{~s}, 60^{\circ} \mathrm{C}$ for $1 \mathrm{~min}$. A 10-fold dilution series of standard DNA was used to obtain the standard curve, which had $0.9625-0.9992 \mathrm{R}^{2}$ values, and the amplification efficiency ranged from $81 \%$ to $89 \%$. The specificity of each PCR assay was confirmed by both melting curve analysis and agarose gel electrophoresis. All the measurements were performed in triplicate.

\subsection{Data Analysis}

The volumetric denitrification rate (Equation (1)), total inorganic nitrogen (TIN) concentration (Equation (2)), and nitrate removal efficiency (Equation (3)) were calculated.

$$
\begin{gathered}
\text { Volumetric denitrification rate }\left(\mathrm{g} \mathrm{NO}_{3}{ }^{-}-\mathrm{N} / \mathrm{m}^{3} \cdot d\right)=\frac{\Delta \mathrm{NO}_{3}{ }^{-}-\mathrm{N} \times \mathrm{V}}{V \times \Delta t} \\
\mathrm{TIN}=\mathrm{NO}_{3}{ }^{-}-\mathrm{N}+\mathrm{NO}_{2}{ }^{-}-\mathrm{N}+\mathrm{NH}_{4}{ }^{+}-\mathrm{N}
\end{gathered}
$$

$\Delta \mathrm{NO}_{3}{ }^{-}-\mathrm{N}\left(\mathrm{mg} \mathrm{L}^{-1}\right)$, the $\mathrm{NO}_{3}{ }^{-}-\mathrm{N}$ concentration difference between any two sampling time $V(\mathrm{~L})$, the effective mesocosm volume

$\Delta t(\mathrm{~d})$, the sampling time interval $\mathrm{NO}_{3}{ }^{-}-\mathrm{N}\left(\mathrm{mg} \mathrm{L}^{-1}\right)$, the $\mathrm{NO}_{3}{ }^{-}-\mathrm{N}$ concentration $\mathrm{NO}_{2}{ }^{-}-\mathrm{N}\left(\mathrm{mg} \mathrm{L}^{-1}\right)$, the $\mathrm{NO}_{2}{ }^{-}-\mathrm{N}$ concentration $\mathrm{NH}_{4}{ }^{+}-\mathrm{N}\left(\mathrm{mg} \mathrm{L}^{-1}\right)$, the $\mathrm{NH}_{4}{ }^{+}-\mathrm{N}$ concentration

$$
\mathrm{NO}_{3}{ }^{-}-\mathrm{N} \text { removal efficiency }(\%)=\frac{\left[\mathrm{NO}_{3}{ }^{-}-\mathrm{N}\right]_{n a}-\left[\mathrm{NO}_{3}{ }^{-}-\mathrm{N}\right]_{(n+1) b}}{\left[\mathrm{NO}_{3}{ }^{-}-\mathrm{N}\right]_{n a}}
$$

$\left[\mathrm{NO}_{3}{ }^{-}-\mathrm{N}\right]_{n a}\left(\mathrm{mg} \mathrm{L}^{-1}\right)$, the $\mathrm{NO}_{3}{ }^{-}-\mathrm{N}$ concentration after the number $n$ time of $\mathrm{NaNO}_{3}$ dosing $\left[\mathrm{NO}_{3}{ }^{-}-\mathrm{N}\right]_{(n+1) b}\left(\mathrm{mg} \mathrm{L}^{-1}\right)$, the $\mathrm{NO}_{3}{ }^{-}-\mathrm{N}$ concentration before the number $(n+1)$ time of $\mathrm{NaNO}_{3}$ dosing

The statistical analysis was carried out using SPSS software (version 23.0, Chicago, IL, USA). The paired-sample $t$-test was used to evaluate the differences between the two mesocosms. 


\section{Results and Discussion}

\subsection{Physical-Chemical Component Variation of H. verticillata}

Cellulose, hemicellulose, and lignin are the main components of H. verticillata (Table 2) [42]. Cellulose and hemicellulose are macromolecules from different sugars, whereas lignin is an aromatic polymer synthesized from phenylpropanoid precursors. After 273 days' decomposition, cellulose and hemicellulose of $H$. verticillata $\left(0.17\right.$ and $0.23 \mathrm{~g} \mathrm{~g}^{-1}$ biomass $^{-1}$ ) decreased to 0.09 and $0.04 \mathrm{~g} \mathrm{~g}^{-1}$ biomass $^{-1}$ in HSHAD mesocosms and 0.15 and $0.03 \mathrm{~g} \mathrm{~g}^{-1}$ biomass $^{-1}$ in HHD mesocosms, which indicated that sulfur does not have adverse effect on biomass decomposition. Lignin increased from $0.05 \mathrm{~g} \mathrm{~g}^{-1}$ biomass $^{-1}$ to $0.22 \mathrm{~g} \mathrm{~g}^{-1}$ biomass $^{-1}$ (HSHAD) and $0.15 \mathrm{~g} \mathrm{~g}^{-1}$ biomass $^{-1}$ (HHD), respectively, at the same time (Table 2).

Table 2. Changes of the main composition at the end of the experiment (per $\mathrm{g}$ H. verticillate pieces).

\begin{tabular}{|c|c|c|c|c|c|c|}
\hline Group & Type & Cellulose $(\mathrm{g}) *$ & Hemicellulose $(\mathrm{g}) *$ & $\operatorname{Lignin}(\mathrm{g}) *$ & $\mathbf{N}(\mathrm{g}) *$ & $P(g) *$ \\
\hline Raw & H. verticillata & 0.17 & 0.23 & 0.05 & 0.02 & 0.01 \\
\hline End in HSHAD & H. verticillata & 0.09 & 0.04 & 0.22 & 0.01 & 0 \\
\hline End in HHD & H. verticillata & 0.15 & 0.03 & 0.15 & 0.01 & 0 \\
\hline
\end{tabular}

* The values were taken from the duplicate samples.

Plant biomass decomposition converts complex organic molecules to simple organic constituents as a result of following processes: (1) physical leaching and fragmentation, (2) extracellular enzyme hydrolysis, (3) aerobic and anaerobic catabolic activities of heterotrophic microorganisms [43]. The high microbial cellulose and hemicellulose utilization (Table 2) indicated that they were likely the main carbon source for $H$. verticillata heterotrophic denitrification in the HSHAD and HHD mesocosms. Cellulose in crystalline form is less susceptible to enzymatic degradation than that in nonorganized form [44]. Crystalline cellulose accounts for a large portion of the total cellulose, which might be responsible for the large portion of the cellulose remaining in H. verticillata (Table 2). Hemicellulose is a complex carbohydrate polymer and more hydrolysable than cellulose $[45,46]$, which explains the reason why most of the hemicellulose was decomposed at the end of the experiment. Lignin is the recalcitrant fraction of the plant biomass, whose microbial utilization requires initial oxygenation [43]. Therefore, the increase of lignin resulted from the nonenzymatic lignin formation and its low degree of microbial utilization [45-48]. Pérez et al. [46] confirmed that the degradation of lignin was difficult due to its structural complexity, insolubility, and high molecular weight. Moreover, 50\% N and 100\% $\mathrm{P}$ were released from $H$. verticillata in both the HSHAD and HHD mesocosms during the 273 days of operation.

\subsection{Principles of the HSHAD Process}

Assuming the main component of the cellulose and hemicellulose in $\mathrm{H}$. verticillata is $\mathrm{C}_{6} \mathrm{H}_{10} \mathrm{O}_{5}$, the stoichiometric equations of $H$. verticillate heterotrophic and sulfur autotrophic denitrification in the HSHAD process can be listed as Equations (4) and (5), respectively:

$$
\begin{gathered}
5 \mathrm{C}_{6} \mathrm{H}_{10} \mathrm{O}_{5}+24 \mathrm{NO}_{3}{ }^{-}+24 \mathrm{H}^{+} \rightarrow 12 \mathrm{~N}_{2}+30 \mathrm{CO}_{2}+37 \mathrm{H}_{2} \mathrm{O} \\
55 \mathrm{~S}^{0}+50 \mathrm{NO}_{3}{ }^{-}+38 \mathrm{H}_{2} \mathrm{O}+20 \mathrm{CO}_{2}+4 \mathrm{NH}_{4}{ }^{+} \rightarrow 4 \mathrm{C}_{5} \mathrm{H}_{7} \mathrm{O}_{2} \mathrm{~N}+55 \mathrm{SO}_{4}{ }^{2-}+25 \mathrm{~N}_{2}+64 \mathrm{H}^{+}
\end{gathered}
$$

Two aspects should be noted for the HSHAD process. The first aspect is its ability to keep $\mathrm{pH}$ balanced without a $\mathrm{pH}$ buffer. According to Equations (4) and (5), $1.0 \mathrm{~mol} \mathrm{\textrm {H } ^ { + }}$ will be consumed when $1.0 \mathrm{~mol} \mathrm{NO}_{3}{ }^{-}-\mathrm{N}$ is denitrified by $H$. verticillata heterotrophic denitrification (H. verticillate pieces as carbon source), and $1.0 \mathrm{~mol} \mathrm{H}{ }^{+}$will be provided when $0.78 \mathrm{~mol} \mathrm{NO}_{3}{ }^{-}-\mathrm{N}$ is reduced to $\mathrm{N}_{2}$ by sulfur autotrophic denitrification. If the mole ratio of nitrate reduction by $H$. verticillata heterotrophic denitrification to that by sulfur autotrophic denitrification is 1:0.78, the $\mathrm{H}^{+}$generated 
by sulfur autotrophic denitrification can be consumed simultaneously by $H$. verticillata heterotrophic denitrification. Thus, a $\mathrm{pH}$ adjustment is not needed. $\mathrm{H}$. verticillata requirement for $1.0 \mathrm{~mol} \mathrm{NO}_{3}{ }^{-}-\mathrm{N}$ reduction and sulfur requirement for $0.78 \mathrm{~mol} \mathrm{NO}_{3}{ }^{-}-\mathrm{N}$ reduction are then determined. Cellulose and hemicellulose of $H$. verticillata are 0.17 and $0.23 \mathrm{~g} / \mathrm{g}$.raw pieces, which account for $40.1 \%$ of the pieces' weight (Table 2), i.e., the $\mathrm{C}_{6} \mathrm{H}_{10} \mathrm{O}_{5}$ component accounts for $40.1 \%$, so the stoichiometric mass ratio of $H$. verticillata pieces to sulfur for $\mathrm{H}^{+}$balance should be 3.1. Since some organic carbons (crystalline cellulose, lignin, etc.) are difficult to decompose and utilize [13], the 5.3 mass ratio of $H$. verticillata to sulfur was applied in this study.

The second aspect relates to the enhancement of denitrification performance. Theoretically, the synergistic improvement of the denitrification performance can be achieved if both the sulfur autotrophic denitrificans and $H$. verticillata heterotrophic denitrificans grow well in the HSHAD system.

\subsection{Mesocosm Performance}

\subsubsection{Carbon Availability}

As depicted in Figure 1a, COD in the control is low and relatively stable. Ingersoll and Baker [49] suggested that the optimum $\mathrm{C} / \mathrm{N}$ ratio for plant biomass heterotrophic denitrification was 4.0-5.0. HSHAD and HHD were operated in three phases based on the $\mathrm{C} / \mathrm{N}$ ratio and its fluctuation. Phase I was the short-term physical leaching period $(0-6 \mathrm{~d}, \mathrm{C} / \mathrm{N}$ ratio $>4.0)$, during which the COD rose quickly to the maximum values (i.e., 204.7 and $352.6 \mathrm{mg} \mathrm{L}^{-1}$ for HSHAD and HHD, respectively) in 1 day (Figure 1a). The rapid COD increase resulted from the fast eluviation of water-soluble substances (i.e., organic acid, protein, and minerals) into water. The dynamic equilibrium between organic carbon release and consumption can be attained on the first day. Then COD gradually decreased to 56.9 and $74.8 \mathrm{mg} \mathrm{L}^{-1}$ in the HSHAD and HHD mesocosms on the sixth day. Phase II (7-118 d, C/N ratio > 4.0) was the long-term steady biological decay period, during which COD was released continuously at lower and steady rate from $H$. verticillata pieces to support the growth of the heterotrophic denitrificans $[47,50]$. In phase I and II, C/N ratios in HSHAD and HHD were both higher than 4.0, which meant sufficient organic carbon for heterotrophic denitrification. Phase III $(119-273 \mathrm{~d}, \mathrm{C} / \mathrm{N}$ ratio $<4.0)$ was the COD reduction period, i.e., COD decreased gradually, which suggested that the carbon release speed was lower than its consumption speed. The average $\mathrm{C} / \mathrm{N}$ ratios in HSHAD and HHD mesocosms were 2.4 and 1.4 in phase III, which meant insufficient organic carbon for heterotrophic denitrification.

The COD variation curve of HSHAD was similar to that of HHD $(p>0.05)$, indicating that there was no significant difference of organic carbon dynamics between HSHAD and HHD mesocosms.

\subsubsection{DOM Analysis}

Four main fluorescence peaks of EEM fluorescence spectra were identified for water samples from different phases (Table 3). EEM spectral regions were related with different organic functional groups in DOM [51]. Peak C1 was located at 250-280/325-370 nm excitation/emission wavelengths (Ex/Em), which was considered as soluble microbial byproduct-like substances [51,52]. Peak C2, which was identified by 225-230/320-340 $\mathrm{nm} \mathrm{Ex} / \mathrm{Em}$, was associated with the aromatic amino acid tryptophan, i.e., protein-like substances [51,53,54]. Peak C3 (260-360/410-460 nm Ex/Em) and Peak C4 (230-250/460-480 $\mathrm{nm} \mathrm{Ex} / \mathrm{Em})$ were described as humic acid-like and fulvic acid-like substances, respectively $[51,52,55,56]$. 

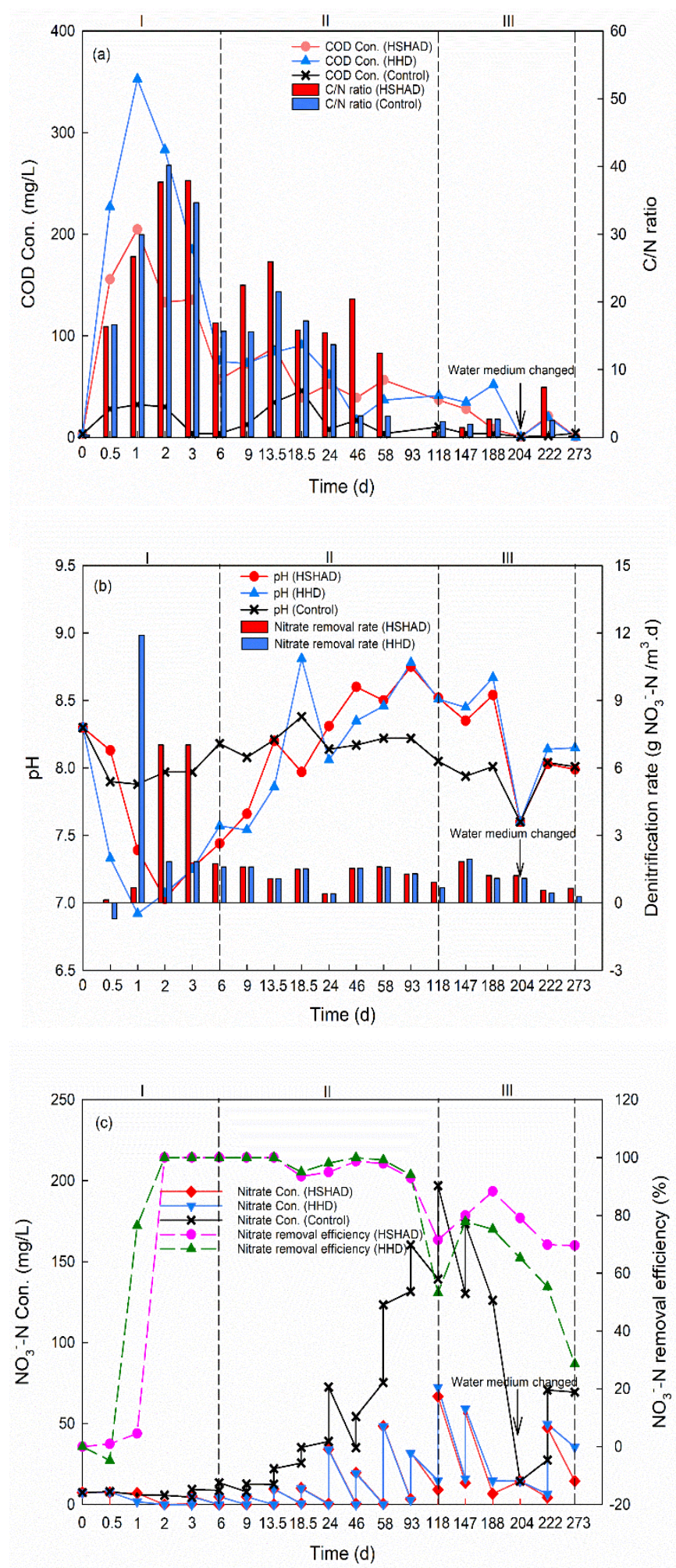

Figure 1. (a) Comparison of $\mathrm{COD}$ and $\mathrm{C} / \mathrm{N}$ ratio profile within each mesocosm; (b) Comparison of $\mathrm{pH}$ and denitrification rate profile within each mesocosm, $p>0.05$; (c) Comparison of $\mathrm{NO}_{3}{ }^{-}-\mathrm{N}$ concentrations and removal efficiency profile within each mesocosm.

Figure 2 and Table 3 illustrate the compositional proportion of each peak intensity in different phases (119-203 d of Phase III), and obvious shifts of peak intensity were observed. From phase I to phase II, rapid decrease of the fluorescence intensity ratio of Peak $(\mathrm{C} 1+\mathrm{C} 2)$ to Peak $(\mathrm{C} 3+\mathrm{C} 4)$ was observed. It can be seen from Figure 2 that massive water-soluble substances (e.g., tryptophan, Peak 
C1) were released initially, and the fulvic acid-like (Peak C3) and humic acid-like (Peak C4) substances were produced throughout the long-term biological decay process. Fluorescence intensity of Peak $(\mathrm{C} 3+\mathrm{C} 4)$ were highest in phase II for all mesocosms.

Table 3. Spectral characteristics of excitation (Ex) and emission (Em) maxima of four components in each phase (Intensity (Int.)).

\begin{tabular}{|c|c|c|c|c|c|c|c|c|c|}
\hline \multirow{2}{*}{ Mesocosm } & \multicolumn{2}{|c|}{ Peak C1 } & \multicolumn{2}{|c|}{ Peak C2 } & \multicolumn{2}{|c|}{ Peak C3 } & \multicolumn{2}{|c|}{ Peak C4 } & \multirow{2}{*}{$\begin{array}{l}\mathrm{C} 1+\mathrm{C} 2 \\
\mathrm{C} 3+\mathrm{C} 4\end{array}$} \\
\hline & $\begin{array}{c}\mathrm{Ex} / \mathrm{Em} \\
(\mathrm{nm})\end{array}$ & $\begin{array}{l}\text { Int. } \\
\text { (r.u.) }\end{array}$ & $\begin{array}{l}\mathrm{Ex} / \mathrm{Em} \\
(\mathrm{nm})\end{array}$ & $\begin{array}{l}\text { Int. } \\
\text { (r.u.) }\end{array}$ & $\mathrm{Ex} / \mathrm{Em}(\mathrm{nm})$ & $\begin{array}{l}\text { Int. } \\
\text { (r.u.) }\end{array}$ & $\begin{array}{c}\mathrm{Ex} / \mathrm{Em} \\
(\mathrm{nm})\end{array}$ & $\begin{array}{l}\text { Int. } \\
\text { (r.u.) }\end{array}$ & \\
\hline $\begin{array}{l}\text { HSHAD } \\
\text { (Phase I) }\end{array}$ & $280 / 340$ & 1138.1 & $230 / 340$ & 310.9 & $\begin{array}{l}330 / 410 \\
360 / 460\end{array}$ & 699.2 & $245 / 460$ & 358.3 & 1.4 \\
\hline $\begin{array}{c}\text { HHD } \\
\text { (Phase I) }\end{array}$ & $270 / 345$ & 1340.9 & $225 / 340$ & 326.7 & $330 / 430$ & 1133.9 & $245 / 460$ & 858.9 & 0.8 \\
\hline $\begin{array}{l}\text { Control } \\
\text { (Phase I) }\end{array}$ & $275 / 325$ & 620.0 & $230 / 320$ & 343.9 & $\mathrm{NA}^{\mathrm{a}}$ & $\mathrm{NA}^{\mathrm{a}}$ & $240 / 480$ & 1467.4 & 0.7 \\
\hline $\begin{array}{l}\text { HSHAD } \\
\text { (Phase II) }\end{array}$ & $\mathrm{NA}^{\mathrm{a}}$ & $\mathrm{NA}^{\mathrm{a}}$ & $\mathrm{NA}^{\mathrm{a}}$ & $\mathrm{NA}^{\mathrm{a}}$ & $\begin{array}{l}325 / 425 \\
275 / 425\end{array}$ & 1808.5 & $230 / 470$ & 2093.5 & 0 \\
\hline $\begin{array}{c}\text { HHD } \\
\text { (Phase II) }\end{array}$ & $\mathrm{NA}^{\mathrm{a}}$ & $\mathrm{NA}^{\mathrm{a}}$ & $\mathrm{NA}^{\mathrm{a}}$ & $\mathrm{NA}^{\mathrm{a}}$ & $\begin{array}{l}330 / 425 \\
275 / 425\end{array}$ & 1659.6 & $230 / 460$ & 3342.2 & 0 \\
\hline $\begin{array}{l}\text { Control } \\
\text { (Phase II) }\end{array}$ & $275 / 325$ & 403.2 & $225 / 325$ & 328.1 & $\begin{array}{l}325 / 425 \\
260 / 425\end{array}$ & 552.0 & $230 / 460$ & 2023.7 & 0.3 \\
\hline $\begin{array}{l}\text { HSHAD } \\
\text { (Phase III) }\end{array}$ & $280 / 370$ & 801.2 & $\mathrm{NA}^{\mathrm{a}}$ & $\mathrm{NA}^{\mathrm{a}}$ & $\begin{array}{l}330 / 420 \\
260 / 420\end{array}$ & 1834.8 & $245 / 460$ & 848.8 & 0.3 \\
\hline $\begin{array}{c}\text { HHD } \\
\text { (Phase III) }\end{array}$ & $280 / 370$ & 624.4 & $\mathrm{NA}^{\mathrm{a}}$ & $\mathrm{NA}^{\mathrm{a}}$ & $\begin{array}{l}330 / 415 \\
260 / 415\end{array}$ & 1842.9 & $250 / 460$ & 1146.3 & 0.2 \\
\hline $\begin{array}{l}\text { Control } \\
\text { (Phase III) }\end{array}$ & $250 / 370$ & 404.7 & $\mathrm{NA}^{\mathrm{a}}$ & $\mathrm{NA}^{\mathrm{a}}$ & $\begin{array}{l}330 / 425 \\
260 / 425\end{array}$ & 760.4 & $\mathrm{NA}^{\mathrm{a}}$ & $\mathrm{NA}^{\mathrm{a}}$ & 0.5 \\
\hline
\end{tabular}

In the compost, the typical mature components were characterized as humic and fulvic acid-like substances (Peak C3 and C4), while the typical immature components contained tryptophan-like substances and soluble microbial byproduct-like substances (Peak C1 and C2) [33]. The decomposition process can be characterized by the degradation of original tyrosine-like and tryptophan-like material (Peak C1 and C2) and the increase of humic and fulvic-like material (Peak C3 and C4) [33,57]. Therefore, it can be concluded from the peak alternation (Figure 2) that the soil and H. verticillata/sulfur (or H. verticillata) mixture in the experimental mesocosms were gradually matured in Phase II, which corresponded to the steady COD concentration and nitrate removal (Figure 1).

Almost no peak was found after 204 days of operation when the water medium of the mesocosms was displaced by the simulated agriculture runoff on the 204th day in phase III (data are not shown), which corresponded to the low COD concentration (around $10.0 \mathrm{mg} / \mathrm{L}$ ) and denitrification rate (Figure 1), and it further confirmed that organic compound release from $\mathrm{H}$. verticillata attained the decline period. 


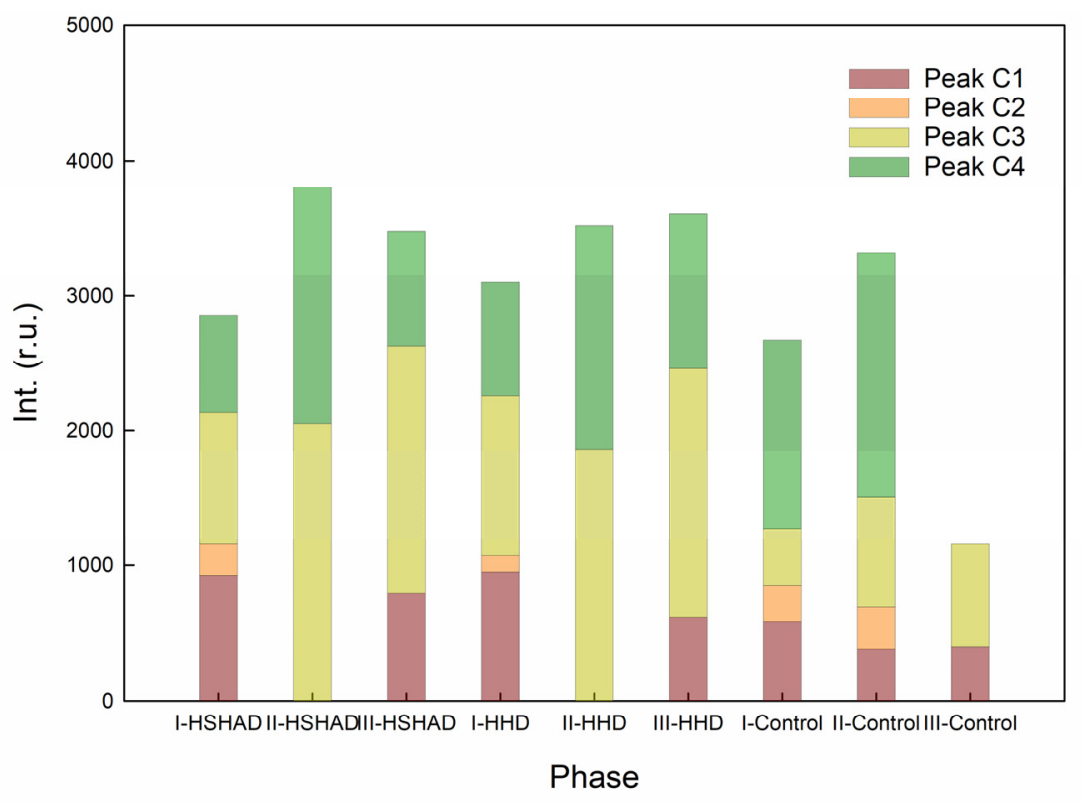

Figure 2. Compositional proportions of different peak intensities for HSHAD and HHD mesocosms during the operation.

\subsubsection{Nitrogen Removal and $\mathrm{SO}_{4}{ }^{2-}$ Generation}

$\mathrm{NO}_{3}{ }^{-}-\mathrm{N}$ removal performance of HSHAD and HHD is shown in Figure 1b,c. Biological denitrification processes need acclimation. In phase $\mathrm{I}$, the denitrification rate rapidly increased to $7.0 \mathrm{~g} \mathrm{NO}_{3}{ }^{-}-\mathrm{N} \mathrm{m}^{-3} \cdot \mathrm{d}^{-1}$ on the second day for HSHAD and $11.9 \mathrm{~g} \mathrm{NO}_{3}{ }^{-}-\mathrm{N} \mathrm{m}^{-3} \cdot \mathrm{d}^{-1}$ on the first day for HHD, then it sharply dropped to 1.7 and $1.8 \mathrm{~g} \mathrm{NO}_{3}{ }^{-}-\mathrm{N} \mathrm{m}^{-3} \cdot \mathrm{d}^{-1}$, respectively, on the sixth day (Figure 1b). During phase II, the denitrification rate remained quite stable with an average of 1.3 and $1.2 \mathrm{~g} \mathrm{NO}_{3}{ }^{-}-\mathrm{N} \mathrm{m}^{-3} \cdot \mathrm{d}^{-1}$ for the HSHAD and HHD mesocosms. In phase III, the average denitrification rates of HSHAD and HHD gradually decreased to 1.1 and $1.0 \mathrm{~g} \mathrm{NO}_{3}{ }^{-}-\mathrm{N} \mathrm{m}^{-3} \cdot \mathrm{d}^{-1}$ because of the absence of organic carbon. A similar trend of denitrification rate was observed for HSHAD and HHD mesocosms, but the average denitrification rate of HSHAD was higher than that of HHD in phase II and III. The denitrification rate of HSHAD gradually increased from the 222th day, but that of HHD still decreased. On the 273th day, the denitrification rate of HSHAD mesocosms $\left(0.7 \mathrm{~g} \mathrm{NO}_{3}{ }^{-}-\mathrm{N} \mathrm{m}^{-3} \cdot \mathrm{d}^{-1}\right)$ was 1.3 times higher than that of HHD mesocosms $\left(0.3 \mathrm{~g} \mathrm{NO}_{3}{ }^{-}-\mathrm{N} \mathrm{m}^{-3} \cdot \mathrm{d}^{-1}\right)$.

For both HSHAD and HHD mesocosms, the same maximum $\mathrm{NO}_{3}{ }^{-}-\mathrm{N}$ removal value $(100.0 \%)$ was achieved on the second day. Then, the $\mathrm{NO}_{3}{ }^{-}-\mathrm{N}$ removal efficiency was maintained above $90.0 \%$ until the 118th day. No statistical differences were observed in $\mathrm{NO}_{3}{ }^{-}-\mathrm{N}$ removal efficiency between HSHAD and HHD mesocosms during phase I and II ( $p>0.05)$ (Figure 1a), which might be due to the sufficient organic carbon released from plant biomass decomposition [17]. After 118 days of operation, organic carbon inadequacy became an obvious limiting factor for $\mathrm{NO}_{3}{ }^{-}-\mathrm{N}$ reduction. $\mathrm{NO}_{3}{ }^{-}-\mathrm{N}$ removal efficiency of HSHAD and HHD both decreased slowly. What is more, $\mathrm{NO}_{3}{ }^{-}-\mathrm{N}$ removal efficiency of HHD decreased faster than that of HSHAD, which demonstrated that the HSHAD process was more effective and efficient than the individual $H$. verticillata heterotrophic dentirification process when the carbon source was insufficient. So the denitrification rate of HSHAD was higher than that of HHD in phase II and III, and the $\mathrm{NO}_{3}{ }^{-}-\mathrm{N}$ removal efficiency of HSHAD was also higher than that of HHD after 118 days of operation. On the 273th day, $\mathrm{NO}_{3}{ }^{-}-\mathrm{N}$ removal efficiency of HSHAD (69.6\%) was still $41.0 \%$ higher than that of HHD $(28.6 \%)$, which might be caused by the combination of sulfur autotrophic denitrification.

Total $\mathrm{NO}_{3}{ }^{-}-\mathrm{N}$ reduction by $\mathrm{HHD}$ was calculated using the stoichiometric equation of the heterotrophic denitrification process (Equation (4)). Theoretically, $912.8 \mathrm{mg} \mathrm{NO}_{3}{ }^{-} \mathrm{N}$ can be reduced by HHD if cellulose and hemicellulose reduced (Table 2 ) in $H$. verticillata pieces were completely 
utilized by heterotrophic denitrification. However, only $557.8 \mathrm{mg} \mathrm{NO}_{3}{ }^{-}-\mathrm{N}$ was eliminated within 273 days of operation, i.e., $61 \%$ of cellulose and hemicellulose reduction was used by heterotrophic denitrification, and the other 39\% might be used by anaerobic and aerobic respiration rather than by heterotrophic denitrification, which was consistent with the 39\% COD consumption for anaerobic and aerobic respiration reported in wetlands [47]. Total $\mathrm{NO}_{3}{ }^{-}-\mathrm{N}$ reduction achieved by HSHAD mesocosms $(616.6 \mathrm{mg}$ ) was $58.8 \mathrm{mg}$ greater than that by HHD mesocosms (557.8 $\mathrm{mg})$, which was attributed to sulfur autotrophic denitrification.

In general, the HSHAD process was split into two major stages in this study. One stage occurred in the period 0-118 d (phase I and II), during which heterotrophic denitrification dominated at higher $\mathrm{C} / \mathrm{N}$ ratio (above 4.0); the other stage spanned 119-273 d (phase III), during which sulfur autotrophic dentirification dominated at lower $\mathrm{C} / \mathrm{N}$ ratio (less than 4.0), which was different from the simultaneous oxidation of sulfur (or thiosulfate) and organic matter by inoculating denitrificans or activated sludge into heterotrophic and autotrophic denitrification systems [20,58-60]. However, this phenomenon agreed well with the findings of Liu et al. [17], i.e., nitrate was primarily reduced by heterotrophic denitrification when the carbon source was adequate, and the residual was subsequently reduced by autotrophic sulfur denitrification. Also, the balanced growth of autotrophic and heterotrophic denitrificans was difficult to achieve without microbial inoculation probably because of the very different growth rates for both bacterial groups [61]. To a great extent, the advantage of HSHAD was its higher nitrate removal capacity and more stable denitrification performance compared with HHD during the later operation period (119-273 d).

To further demonstrate the critical function of sulfur autotrophic denitrification during the later carbon-limited period (119-273 d), $\mathrm{SO}_{4}{ }^{2-}$ concentrations for HSHAD, HHD, and control mesocosms were analyzed (Figure 3). No notable differences were observed in $\mathrm{SO}_{4}{ }^{2-}$ concentrations between the HSHAD and HHD mesocosms until the 93th day. A total of $680.2 \mathrm{mg}$ more $\mathrm{SO}_{4}{ }^{2-}$ was produced in HSHAD mesocosms in comparison to HHD during the whole operation. This occurred because $\mathrm{SO}_{4}{ }^{2-}$ concentrations increased after 46 days of operation (Figure 3) with higher proportion of $\mathrm{NO}_{3}{ }^{-}-\mathrm{N}$ reduced by sulfur autotrophic denitrification in the HSHAD mesocosms.

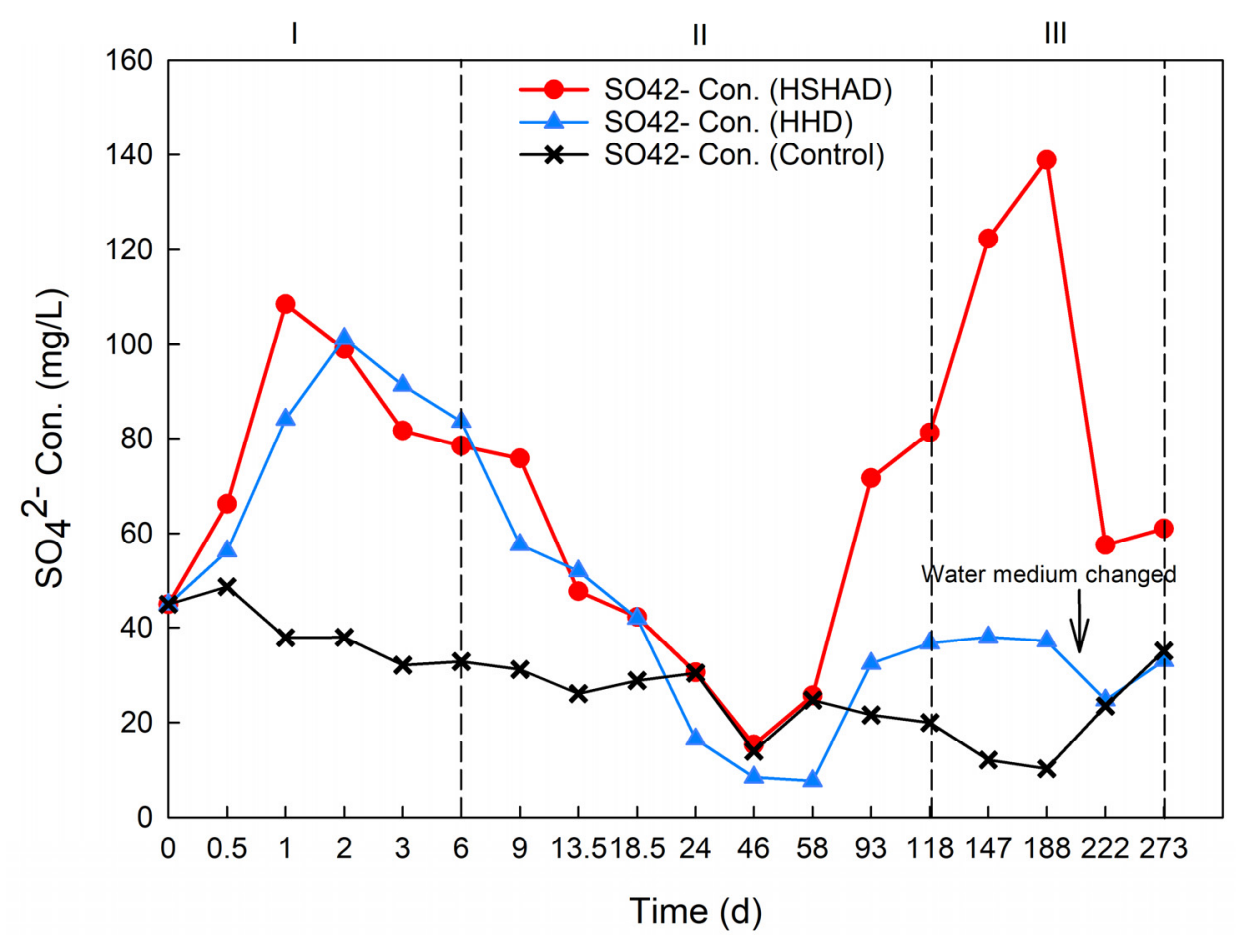

Figure 3. $\mathrm{SO}_{4}{ }^{2-}$ characteristics of each mesocosm during the experimental period. 
In fact, corresponding to the extra $58.8 \mathrm{mg} \mathrm{NO}_{3}{ }^{-}-\mathrm{N}$ reduction in HSHAD mesocosms, $443.6 \mathrm{mg}$ $\mathrm{SO}_{4}{ }^{2-}$ should be produced, based on Equation (5), which was lower than the measured value of $680.2 \mathrm{mg}$. This phenomenon suggests that $\mathrm{SO}_{4}{ }^{2-}$ generation did not completely obey the stoichiometric relationship due to sulfite and thiosulfate formation by some intermediate reaction processes [31,62].

Concentrations of $\mathrm{NH}_{4}{ }^{+}-\mathrm{N}, \mathrm{NO}_{2}{ }^{-}-\mathrm{N}$ and TP during different phases were also analyzed. Average $\mathrm{NO}_{2}{ }^{-}-\mathrm{N}$ concentrations were 1.7 (2.0), 2.9 (2.8) and $1.9(2.0) \mathrm{mg} \mathrm{L}^{-1}$ for HSHAD (HHD) mesocosms in phase I, II, and III. By comparison with the data for HSHAD, HHD, and control, fast nutrient release from H. verticillata at the beginning (phase I) resulted in a sharp increase in $\mathrm{NH}_{4}{ }^{+}-\mathrm{N}$ and TP concentrations for both HSHAD and HHD mesocosms, which was similar with former research [48,63-65]. However, at phase II and III, $\mathrm{NH}_{4}{ }^{+}-\mathrm{N}$ and TP concentrations averaged 1.1 (1.2) and $1.0(0.9) \mathrm{mg} / \mathrm{L}$ for HSHAD (HHD) mesocosms, which demonstrated that the initial $\mathrm{NH}_{4}{ }^{+}-\mathrm{N}$ and TP accumulation can be successfully removed after phase I. Presumably, the effluent $\mathrm{NH}_{4}{ }^{+}-\mathrm{N}, \mathrm{NO}_{2}{ }^{-}-\mathrm{N}$, and TP can be less likely accumulated if the experiment was operated in a continuous feeding mode.

\subsection{4. $\mathrm{pH}$ Change}

The $\mathrm{pH}$ in both HSHAD and HHD mesocosms presented a similar trend and fluctuated between 6.9 and 9.0 throughout the entire operation (Figure 1b). The pH of HSHAD mesocosms sharply decreased from 8.3 to a minimum value of 7.0 on the second day, and slowly increased to 8.8 on the 93th day, and then declined to 7.6 on the 204th day. The sharp pH decrease within two days may have been caused by aerobic respiration. In phase III, the $\mathrm{pH}$ of the HSHAD mesocosms was slightly lower than that of $\mathrm{HHD}$, which resulted from more $\mathrm{NO}_{3}{ }^{-}-\mathrm{N}$ removal by sulfur autotrophic denitrification. $\mathrm{pH}$ had a closed relation with denitrificans growth, and therefore influenced denitrification performance [66]. The optimum $\mathrm{pH}$ for most strains of heterotrophic denitrificans is 7.0-8.0 [67,68], while that for sulfur autotrophic denitrificans is 7.7-8.6 [68]. After 46 days of operation, $\mathrm{pH}$ in both of HSHAD and HHD exceeded the optimum range for heterotrophic denitrificans growth (Figure 1b), which may have led to the decline of denitrification performance. After 9 days of operation, the $\mathrm{pH}$ in HSHAD was within the optimum range for autotrophic denitrificans. Sulfur autotrophic denitrificans could grow well under such $\mathrm{pH}$ conditions in HSHAD, which resulted in the higher denitrification capability of HSHAD than HHD in phase II and phase III.

\subsection{Mesocosm Denitrifying Genes}

The total abundance of denitrifying genes (narG, nirS, and nosZ) in the mesocosms were calculated using their corresponding genes copies to the weight of the DNA samples, and the average abundance of denitrifying genes with standard errors in bottom soil and in mixture from litter bags for HSHAD, HHD, and control mesocosms on the 273th day are illustrated and characterized in Figure 4a-c.

The nirS genes in the bottom soil and mixture from litter bags of HSHAD mesocosms were $1.7 \times 10^{8} \pm 3.7 \times 10^{7}$ copies $\mathrm{g}^{-1}$ soil $^{-1}$ and $4.1 \times 10^{7} \pm 3.4 \times 10^{5}$ copies g $^{-1}$ mixture $^{-1}$, which were much higher than those of HHD mesocosms $\left(7.3 \times 10^{7} \pm 7.6 \times 10^{6}\right.$ copies g $^{-1}$ soil $^{-1}$ and $2.9 \times 10^{7} \pm$ $2.7 \times 10^{7}$ copies $^{-1}$ mixture $^{-1}$ ) (Figure $4 \mathrm{~b}$ ). The nosZ genes in the bottom soil presented the same trend as nirS genes, and their abundance in HSHAD mesocosms $\left(2.5 \times 10^{6} \pm 4.4 \times 10^{5}\right.$ copies g $^{-1}$ soil $\left.^{-1}\right)$ was higher than that in HHD mesocosms $\left(1.6 \times 10^{6} \pm 3.5 \times 10^{5}\right.$ copies g $^{-1}$ soil $\left.^{-1}\right)$ (Figure $4 \mathrm{c}$ ). Similarly, the abundance of narG genes $\left(3.2 \times 10^{8} \pm 1.2 \times 10^{8}\right.$ copies g $^{-1}$ soil $\left.^{-1}\right)$ in the bottom soil of HSHAD mesocosms was greater than that of HHD mesocosms $\left(1.3 \times 10^{8} \pm 2.8 \times 10^{7}\right.$ copies g $^{-1}$ soil $\left.^{-1}\right)$ (Figure 4a). The narG, nirS, and nosZ genes in the bottom soil and the nirS genes in the mixture of HSHAD mesocosms were all higher than those of HHD mesocosms, and one possible explanation was that the combined heterotrophic and autotrophic process could have improved the growth of denitrificans with narG, nirS, nos Z genes in the bottom soil and nirS in the mixture of HSHAD. However, the nos $Z$ and narG genes in the mixture from the litter bags of HSHAD mesocosms were $9.8 \times 10^{5}$ $\pm 3.1 \times 10^{4}$ and $7.5 \times 10^{7} \pm 1.3 \times 10^{7}$ copies $^{-1}$ mixture $^{-1}$, which were similar with those of HHD mesocosms $\left(9.5 \times 10^{5} \pm 3.9 \times 10^{4}\right.$ and $8.0 \times 10^{7} \pm 4.8 \times 10^{7}$ copies $^{-1}$ mixture $\left.^{-1}\right)$ (Figure $\left.4 a, c\right)$. 

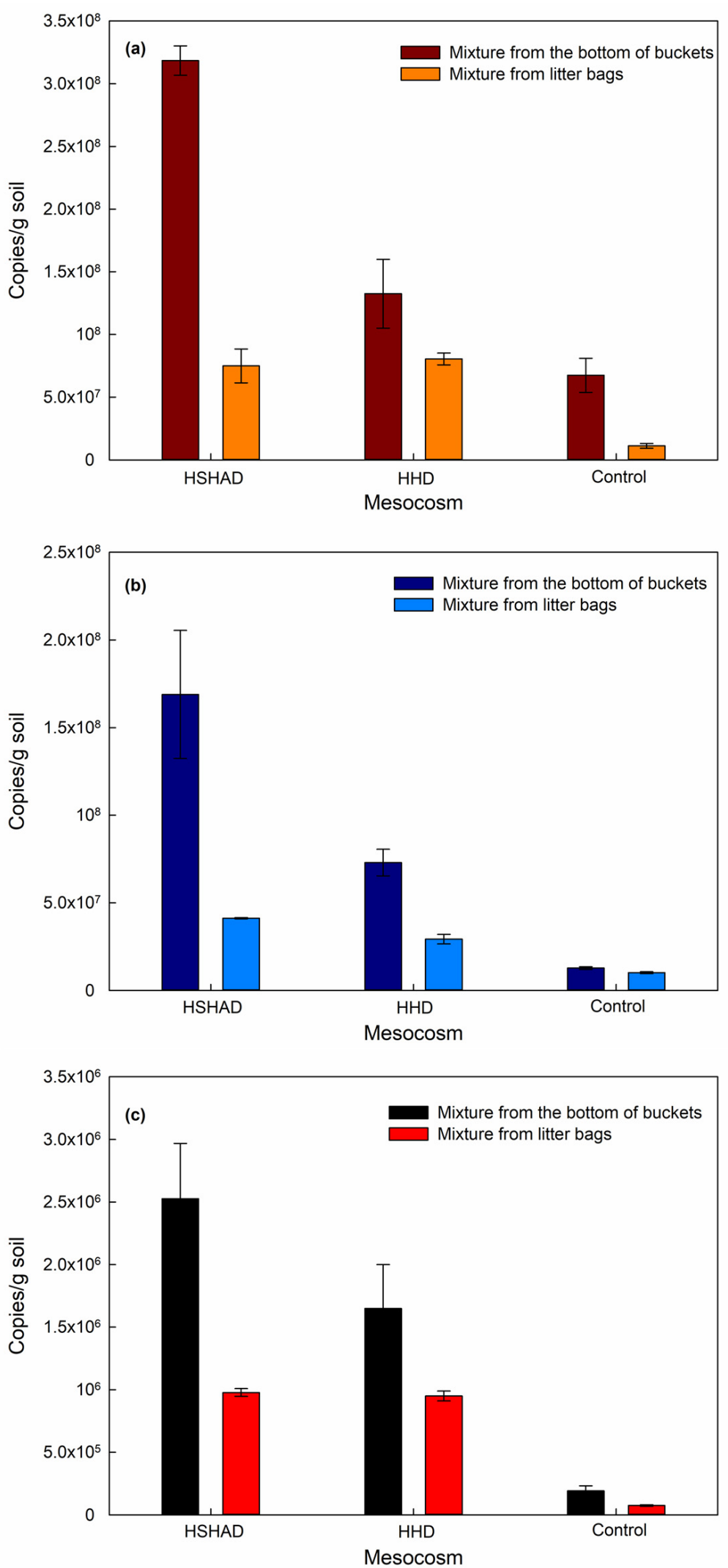

Figure 4. The abundance of denitrifying $\operatorname{narG}(\mathbf{a})$, nirS (b), and nosZ (c) genes in mesocosms (error bars represent standard errors of the mean value).

The total denitrificans genes content of the mesocosms was calculated using all the genes copies to the total weight of the litter bag mixture DNA sample and bottom DNA sample. The results showed 
that HSHAD could supply more favorable circumstances for the growth of denitrificans containing nar $G$ $\left(1.7 \times 10^{8} \pm 1.3 \times 10^{7}\right.$ copies g $^{-1}$ mixture-soil $\left.^{-1}\right), \operatorname{nir} S\left(8.2 \times 10^{7} \pm 8.9 \times 10^{6}\right.$ copies g $^{-1}$ mixture-soil $\left.^{-1}\right)$, and nosZ $\left(1.6 \times 10^{6} \pm 1.6 \times 10^{5}\right.$ copies $^{-1}$ mixture-soil $\left.^{-1}\right)$ than HHD, i.e., $1.0 \times 10^{8} \pm 1.0 \times 10^{7}$, $4.9 \times 10^{7} \pm 4.9 \times 10^{6}$ and $1.3 \times 10^{6} \pm 1.8 \times 10^{5}$ copies $^{-1}$ mixture-soil $^{-1}$, respectively (Figure 4). It can be deduced that sulfur addition might contribute to the increase of nar $G$, nirS, and nosZ genes in HSHAD. So the HSHAD had better denitrification performance than HHD in phase III. The total abundance of narG, nirS, and nosZ genes $\left(4.2 \times 10^{7} \pm 6.6 \times 10^{6}, 1.2 \times 10^{7} \pm 5.2 \times 10^{5}\right.$ and $1.4 \times 10^{5} \pm$ $2.1 \times 10^{4}$ copies $^{-1}$ mixture-soil $^{-1}$ ) in control mesocosms were much less than those in HSHAD and HHD mesocosms, which demonstrated the positive role played by the H. verticillata carbon sources in the growth of denitrifying bacteria.

The abundance of nosZ genes was lower than that of narG and nirS genes, which was similar to previous studies $[69,70]$. The nos $Z$ genes catalyzed the reduction of $\mathrm{N}_{2} \mathrm{O}$ to $\mathrm{N}_{2}$ and enhanced the growth of bacteria containing the nos $\mathrm{Z}$ gene, thus reduced the emission of $\mathrm{N}_{2} \mathrm{O}$. However, it has been reported that approximately one-third of genome denitrifying bacteria have $\mathrm{N}_{2} \mathrm{O}$ reductase [71].

\subsection{Comparison of HSHAD with Other HAD Processes}

The nitrate removal performance of the HSHAD process was compared to that of other HAD processes, based on literature survey, and the packed fillers and the highest removal capacity of each process are listed in Table 4. In a pilot-scale, horizontal-flow constructed wetland, only $67.0 \% \mathrm{NO}_{3}{ }^{-}-\mathrm{N}$ removal efficiency was attained because of inadequate influent organic carbon [20,60]; however, the HSHAD mesocosms could attain the high $\mathrm{NO}_{3}{ }^{-}-\mathrm{N}$ removal efficiency $(100 \%)$. In bioreactors, most HAD processes could achieve above $89.0 \% \mathrm{NO}_{3}{ }^{-}-\mathrm{N}$ removal efficiency with the highest denitrification rate of $5050.0 \mathrm{~g} \mathrm{NO}_{3}{ }^{-}-\mathrm{N} / \mathrm{m}^{3} \cdot \mathrm{d}$ (Table 4), and HSHAD mesocosms could attain the highest $\mathrm{NO}_{3}{ }^{-}-\mathrm{N}$ removal efficiency $(100 \%)$ as the reported HAD bioreactors (89-100\%). The highest denitrification rate of HSHAD $\left(7.0 \mathrm{~g} \mathrm{NO}_{3}{ }^{-}-\mathrm{N} \mathrm{m}^{-3} \mathrm{~d}^{-1}\right)$ was close to the double-layer permeable reactive barrier $\left(9.5 \mathrm{~g} \mathrm{NO}_{3}{ }^{-}-\mathrm{N} \mathrm{m}^{-3} \mathrm{~d}^{-1}\right)$ and the packed-bed bioreactor $\left(5.0 \mathrm{~g} \mathrm{NO}_{3}{ }^{-}-\mathrm{N} \mathrm{m}^{-3} \cdot \mathrm{d}^{-1}\right)[19,21]$, but was lower than other reported bioreactors (5.0-5050.0 $\left.\mathrm{g} \mathrm{NO}_{3}^{-}-\mathrm{N} \mathrm{m}^{-3} \mathrm{~d}^{-1}\right)[17,28,31,60,72-74]$. Different denitrification performance probably resulted from the abundance of denitrifying bacteria, reactor configuration, type of carbon source, denitrification microenvironment, operation conditions, etc. Therefore, the optimum parameters (e.g., plant biomass species, mass ratio of plant biomass/sulfur, soil types, dosing positions of plant biomass, sulfur, etc.) should be further investigated to obtain more desirable nitrate removal performance by HSHAD in free water surface constructed wetlands. 
Table 4. Comparison of biological denitrification capacity among different approaches.

\begin{tabular}{|c|c|c|c|c|c|}
\hline $\begin{array}{l}\text { Denitrification } \\
\text { Approach }\end{array}$ & Packing Material/Electron Donors & System Description & $\begin{array}{c}\text { Maximum Nitrate } \\
\text { Removal Efficiency (\%) }\end{array}$ & $\begin{array}{c}\text { Maximum Nitrate } \\
\text { Denitrification Rate }\left(\mathrm{g} \mathrm{m}^{-3} \cdot \mathrm{d}^{-1}\right)\end{array}$ & References \\
\hline HSHAD & Sulfur/H. verticillata/gravel/wetland and paddy soil & $\begin{array}{l}\text { Free water surface constructed } \\
\text { wetland mesocosm }\end{array}$ & 100 & 7.0 & This study \\
\hline HAD & $\begin{array}{c}\text { Sulfur/methanol/anaerobic sludge/sulfur autotrophic } \\
\text { denitrificans }\end{array}$ & Sulfur packed bed reactor & 89 & $5050.0^{\mathrm{b}}$ & [60] \\
\hline HAD & Sulfur/methanol/aerobic and anaerobic sludge/ & $\begin{array}{l}\text { Sulfur particle master culture } \\
\text { reactor }\end{array}$ & $>97^{\mathrm{b}}$ & $1920.0^{\mathrm{b}}$ & [28] \\
\hline HAD & $\begin{array}{c}\text { Sulfur/acetate/anaerobic sludge/sulfur autotrophic } \\
\text { denitrificans }\end{array}$ & $\begin{array}{l}\text { Sulfur particle master culture } \\
\text { reactor }\end{array}$ & $100^{b}$ & $98.9^{\mathrm{b}}$ & [73] \\
\hline HAD & $\begin{array}{l}\text { Pine bark/spongy iron/sand/gravel/heterotrophic and } \\
\text { autotrophic denitrificans }\end{array}$ & $\begin{array}{l}\text { Double-layer permeable } \\
\text { reactive barrier }\end{array}$ & $99^{b}$ & $9.5^{\mathrm{b}}$ & [21] \\
\hline HAD & $\begin{array}{l}\text { Sulfide/sulfide-degrading bacteria (Pseudomonas sp. } \\
\text { C27)/acetate }\end{array}$ & Expanded granular sludge bed & $100^{\mathrm{b}}$ & $\mathrm{NA}^{\mathrm{a}}$ & [75] \\
\hline HAD & $\begin{array}{c}\text { Sulfur/heterotrophic and autotrophic } \\
\text { denitrificans/methanol }\end{array}$ & Fluidized bed reactor & $-100^{\mathrm{b}}$ & $1440.0^{\mathrm{b}}$ & [17] \\
\hline HAD & Cotton/zero valent iron (R4)/bacteria inoculation & Double layer column reactor & $-100^{b}$ & $275.0^{\mathrm{b}}$ & [72] \\
\hline HAD & Sulfide/acetate & $\begin{array}{l}\text { Anaerobic continuous stirred } \\
\text { tank reactor }\end{array}$ & 100 & $-13.8^{b}$ & [74] \\
\hline HAD & Sulfur/limestone/methanol & $\begin{array}{l}\text { Lab-scale packed-bed } \\
\text { bioreactor }\end{array}$ & $100^{b}$ & $5.0^{\mathrm{b}}$ & [19] \\
\hline HAD & Methanol/anaerobic sludge & $\begin{array}{l}\text { Intensified biofilm-electrode } \\
\text { reactor }\end{array}$ & 97 & -146.0 & [22] \\
\hline HAD & Thiobacillus bacteria inoculation/sulfur/limestone & Pilot-scale horizontal flow CW & $-67^{b}$ & $\mathrm{NA}^{\mathrm{a}}$ & [20] \\
\hline HAD & Ethanol/sulfur sesquioxide/anaerobic sludge & Serum bottle reactor & $100^{\mathrm{b}}$ & $\mathrm{NA}^{\mathrm{a}}$ & [76] \\
\hline
\end{tabular}

${ }^{a}$ No data available. ${ }^{b}$ Estimated or calculated based on the data of the references. 


\section{Conclusions}

To effectively treat nitrate-rich agricultural runoff with low $\mathrm{C} / \mathrm{N}$ ratio, the HSHAD process in free water surface constructed wetland mesocosms was put forward, and its performance was extensively evaluated and compared with that of HHD in mesocosms through a 273-day operation.

1. Heterotrophic and autotrophic denitrification can be combined in the HSHAD process, i.e., the former process mainly dominated $\mathrm{NO}_{3}{ }^{-}-\mathrm{N}$ reduction during the $0-118$ days of operation with 4.0 or higher $\mathrm{C} / \mathrm{N}$ ratio, while the latter process dominated during 119-273 days of the operation.

2. The average $\mathrm{NO}_{3}{ }^{-}-\mathrm{N}$ removal efficiency and denitrification rate of HSHAD mesocosms were $94.4 \%$ and $1.3 \mathrm{~g} \mathrm{NO}_{3}{ }^{-}-\mathrm{N} \mathrm{m}^{-3} \cdot \mathrm{d}^{-1}$ in steady phase II (7-118 d). The HSHAD process was much more efficient and stable than the HHD process in the long-term operation. At the end of the experiment, the $\mathrm{NO}_{3}{ }^{-}-\mathrm{N}$ removal efficiency of HSHAD mesocosms $(69.6 \%)$ was $41.0 \%$ higher than that of HHD mesocosms (28.6\%). The rapid increase of $\mathrm{NH}_{4}{ }^{+}-\mathrm{N}, \mathrm{NO}_{2}{ }^{-}-\mathrm{N}$, and TP concentration in the beginning did not affect the HSHAD denitrification performance, and a $\mathrm{pH}$ buffer was not necessary for its moderate fluctuation throughout the operation.

3. The combination of $H$. verticillate pieces heterotrophic and sulfur autotrophic denitrification led to the higher total abundance of denitrificans containing narG $\left(1.67 \times 10^{8} \pm 1.28 \times 10^{7}\right.$ copies $^{-1}$ mixture-soil $\left.{ }^{-1}\right)$, nirS $\left(8.25 \times 10^{7} \pm 8.95 \times 10^{6}\right.$ copies $^{-1}$ mixture-soil $\left.^{-1}\right)$, and nosZ $\left(1.56 \times 10^{6} \pm\right.$ $1.60 \times 10^{5}$ copies $^{-1}$ mixture-soil $\left.{ }^{-1}\right)$ in the litter bags and bottoms of HSHAD mesocosms than that of HHD, which thus resulted in better denitrification performance.

Author Contributions: Q.H. conceived and conducted the experiments, as well as sampling and monitoring while H.W. supervised. Q.H., H.W., Z.H., and Z.C. drafted the paper. W.D., Y.L., G.Y., Y.C., and C.L. provided critical revision of the manuscript. All authors have read and agreed to the published version of the manuscript.

Funding: This study was funded by National Major Science and Technology Program for Water Pollution Control and Treatment (2017ZX07401003-05; 2012ZX07105-002) and China Scholarship Council Foundation (2011911098).

Acknowledgments: The authors would like to thank Yanhua Wang, Miao Liao, and Bin Yang for their helpful collaboration.

Conflicts of Interest: The authors declare no conflict of interest.

\section{References}

1. Mirvish, S.S. N-nitroso compounds, nitrite, and nitrate: Possible implications for the causation of human cancer. In Proceedings of the Conference on Nitrogen as a Water Pollutant; Elsevier: Amsterdam, The Netherlands, 2013; pp. 195-207.

2. Ballantine, K.A.; Groffman, P.M.; Lehmann, J.; Schneider, R.L. Stimulating nitrate removal processes of restored wetlands. Environ. Sci. Technol. 2014, 48, 7365-7373. [CrossRef]

3. Iamchaturapatr, J.; Yi, S.W.; Rhee, J.S. Nutrient removals by 21 aquatic plants for vertical free surface-flow (VFS) constructed wetland. Ecol. Eng. 2007, 29, 287-293. [CrossRef]

4. Bachand, P.A.; Horne, A.J. Denitrification in constructed free-water surface wetlands: II. Effects of vegetation and temperature. Ecol. Eng. 1999, 14, 17-32. [CrossRef]

5. Mander, Ü.; Tournebize, J.; Kasak, K.; Mitsch, W.J. Climate regulation by free water surface constructed wetlands for wastewater treatment and created riverine wetlands. Ecol. Eng. 2014, 72, 103-115. [CrossRef]

6. Kadlec, R.H.; Wallace, S. Treatment Wetlands; CRC Press: Boca Raton, FL, USA, 2008.

7. Vymazal, J. Constructed wetlands for wastewater treatment. Water 2010, 2, 103-115. [CrossRef]

8. Spieles, D.J.; Mitsch, W.J. The effects of season and hydrologic and chemical loading on nitrate retention in constructed wetlands: A comparison of low-and high-nutrient riverine systems. Ecol. Eng. 1999, 14, 77-91. [CrossRef]

9. Moon, H.S.; Chang, S.W.; Nam, K.; Choe, J.; Kim, J.Y. Effect of reactive media composition and co-contaminants on sulfur-based autotrophic denitrification. Environ. Pollut. 2006, 144, 802-807. [CrossRef]

10. Soares, M. Denitrification of groundwater with elemental sulfur. Water Res. 2002, 36, 1392-1395. [CrossRef] 
11. Her, J.-J.; Huang, J.-S. Influences of carbon source and C/N ratio on nitrate/nitrite denitrification and carbon breakthrough. Bioresour. Technol. 1995, 54, 45-51. [CrossRef]

12. Hang, Q.; Wang, H.; Chu, Z.; Ye, B.; Li, C.; Hou, Z. Application of plant carbon source for denitrification by constructed wetland and bioreactor: Review of recent development. Environ. Sci. Pollut. Res. 2016, 23, 8260-8274. [CrossRef]

13. Chen, Y.; Wen, Y.; Cheng, J.; Xue, C.; Yang, D.; Zhou, Q. Effects of dissolved oxygen on extracellular enzymes activities and transformation of carbon sources from plant biomass: Implications for denitrification in constructed wetlands. Bioresour. Technol. 2011, 102, 2433-2440. [CrossRef] [PubMed]

14. Ovez, B. Batch biological denitrification using Arundo donax, Glycyrrhiza glabra, and Gracilaria verrucosa as carbon source. Process Biochem. 2006, 41, 1289-1295. [CrossRef]

15. Park, J.; Craggs, R.; Sukias, J. Treatment of hydroponic wastewater by denitrification filters using plant prunings as the organic carbon source. Bioresour. Technol. 2008, 99, 2711-2716. [CrossRef] [PubMed]

16. Soares, M.I.M.; Abeliovich, A. Wheat straw as substrate for water denitrification. Water Res. 1998, 32, 3790-3794. [CrossRef]

17. Liu, H.; Jiang, W.; Wan, D.; Qu, J. Study of a combined heterotrophic and sulfur autotrophic denitrification technology for removal of nitrate in water. J. Hazard. Mater. 2009, 169, 23-28. [CrossRef]

18. Zhao, Y.; Zhang, B.; Feng, C.; Huang, F.; Zhang, P.; Zhang, Z.; Yang, Y.; Sugiura, N. Behavior of autotrophic denitrification and heterotrophic denitrification in an intensified biofilm-electrode reactor for nitrate-contaminated drinking water treatment. Bioresour. Technol. 2012, 107, 159-165. [CrossRef]

19. Sahinkaya, E.; Dursun, N.; Kilic, A.; Demirel, S.; Uyanik, S.; Cinar, O. Simultaneous heterotrophic and sulfur-oxidizing autotrophic denitrification process for drinking water treatment: Control of sulfate production. Water Res. 2011, 45, 6661-6667. [CrossRef]

20. Park, J.-H.; Kim, S.-H.; Delaune, R.D.; Cho, J.-S.; Heo, J.-S.; Ok, Y.S.; Seo, D.-C. Enhancement of nitrate removal in constructed wetlands utilizing a combined autotrophic and heterotrophic denitrification technology for treating hydroponic wastewater containing high nitrate and low organic carbon concentrations. Agric. Water Manag. 2015, 162, 1-14. [CrossRef]

21. Huang, G.; Huang, Y.; Hu, H.; Liu, F.; Zhang, Y.; Deng, R. Remediation of nitrate-nitrogen contaminated groundwater using a pilot-scale two-layer heterotrophic-autotrophic denitrification permeable reactive barrier with spongy iron/pine bark. Chemosphere 2015, 130, 8-16. [CrossRef]

22. Zhao, Y.; Feng, C.; Wang, Q.; Yang, Y.; Zhang, Z.; Sugiura, N. Nitrate removal from groundwater by cooperating heterotrophic with autotrophic denitrification in a biofilm-electrode reactor. J. Hazard. Mater. 2011, 192, 1033-1039. [CrossRef]

23. Wang, Z.; Jiang, Y.; Awasthi, M.K.; Wang, J.; Yang, X.; Amjad, A.; Wang, Q.; Lahori, A.H.; Zhang, Z. Nitrate removal by combined heterotrophic and autotrophic denitrification processes: Impact of coexistent ions. Bioresour. Technol. 2018, 250, 838-845. [CrossRef] [PubMed]

24. Sahinkaya, E.; Kilic, A. Heterotrophic and elemental-sulfur-based autotrophic denitrification processes for simultaneous nitrate and Cr (VI) reduction. Water Res. 2014, 50, 278-286. [CrossRef] [PubMed]

25. Xu, D.; Xiao, E.; Xu, P.; Lin, L.; Zhou, Q.; Xu, D.; Wu, Z. Bacterial community and nitrate removal by simultaneous heterotrophic and autotrophic denitrification in a bioelectrochemically-assisted constructed wetland. Bioresour. Technol. 2017, 245, 993-999. [CrossRef] [PubMed]

26. Hang, Q.; Wang, H.; Chu, Z.; Hou, Z.; Zhou, Y.; Li, C. Nitrate-rich agricultural runoff treatment by Vallisneria-sulfur based mixotrophic denitrification process. Sci. Total Environ. 2017, 587, 108-117. [CrossRef] [PubMed]

27. Kim, S.; Jung, H.; Kim, K.-S.; Kim, I.S. Treatment of high nitrate-containing wastewaters by sequential heterotrophic and autotrophic denitrification. J. Environ. Eng. 2004, 130, 1475-1480. [CrossRef]

28. Oh, S.; Yoo, Y.; Young, J.; Kim, I. Effect of organics on sulfur-utilizing autotrophic denitrification under mixotrophic conditions. J. Biotechnol. 2001, 92, 1-8. [CrossRef]

29. Sahinkaya, E.; Kilic, A.; Calimlioglu, B.; Toker, Y. Simultaneous bioreduction of nitrate and chromate using sulfur-based mixotrophic denitrification process. J. Hazard. Mater. 2013, 262, 234-239. [CrossRef]

30. Zhang, L.; Zhang, C.; Hu, C.; Liu, H.; Bai, Y.; Qu, J. Sulfur-based mixotrophic denitrification corresponding to different electron donors and microbial profiling in anoxic fluidized-bed membrane bioreactors. Water Res. 2015, 85, 422-431. [CrossRef] 
31. Li, R.; Feng, C.; Hu, W.; Xi, B.; Chen, N.; Zhao, B.; Liu, Y.; Hao, C.; Pu, J. Woodchip-sulfur based heterotrophic and autotrophic denitrification (WSHAD) process for nitrate contaminated water remediation. Water Res. 2016, 89, 171-179. [CrossRef]

32. Sheng, G.P.; Yu, H.Q. Characterization of extracellular polymeric substances of aerobic and anaerobic sludge using three-dimensional excitation and emission matrix fluorescence spectroscopy. Water Res. 2006, 40, 1233-1239. [CrossRef]

33. Yu, G.-H.; Luo, Y.-H.; Wu, M.-J.; Tang, Z.; Liu, D.-Y.; Yang, X.-M.; Shen, Q.-R. PARAFAC modeling of fluorescence excitation-Emission spectra for rapid assessment of compost maturity. Bioresour. Technol. 2010, 101, 8244-8251. [CrossRef] [PubMed]

34. Brinson, M.M. Decomposition and nutrient exchange of litter in an alluvial swamp forest. Ecology 1977, 58, 601-609. [CrossRef]

35. Meyer, J.L. Dynamics of phosphorus and organic matter during leaf decomposition in a forest stream. Oikos 1980, 34, 44-53. [CrossRef]

36. Triska, F.; Sedell, J. Decomposition of four species of leaf litter in response to nitrate manipulation. Ecology 1976, 57, 783-792. [CrossRef]

37. Zhou, X.; Zhou, Y.; Zhou, C.; Wu, Z.; Zheng, L.; Hu, X.; Chen, H.; Gan, J. Effects of cutting intensity on soil physical and chemical properties in a mixed natural forest in southeastern China. Forests 2015, 6, 4495-4509. [CrossRef]

38. Association, A.P.H.; Association, A.W.W.; Federation, W.P.C.; Federation, W.E. Standard Methods for the Examination of Water and Wastewater; American Public Health Association: Washington, DC, USA, 1998; Volume 2.

39. López-Gutiérrez, J.C.; Henry, S.; Hallet, S.; Martin-Laurent, F.; Catroux, G.; Philippot, L. Quantification of a novel group of nitrate-reducing bacteria in the environment by real-time PCR. J. Microbiol. Methods 2004, 57, 399-407. [CrossRef]

40. Zhou, Z.; Zheng, Y.; Shen, J.; Zhang, L.; Liu, Y.; He, J. Responses of activities, abundances and community structures of soil denitrifiers to short-term mercury stress. J. Environ. Sci. 2012, 24, 369-375. [CrossRef]

41. Yu, Z.; Yang, J.; Liu, L. Denitrifier community in the oxygen minimum zone of a subtropical deep reservoir. PLoS ONE 2014, 9, e92055. [CrossRef]

42. Yang, H.; Yan, R.; Chen, H.; Lee, D.H.; Zheng, C. Characteristics of hemicellulose, cellulose and lignin pyrolysis. Fuel 2007, 86, 1781-1788. [CrossRef]

43. DeLaune, R.D.; Reddy, K.R. Biogeochemistry of Wetlands: Science and Applications; CRC Press: Amsterdam, The Netherlands, 2008.

44. Béguin, P.; Aubert, J.-P. The biological degradation of cellulose. FEMS Microbiol. Rev. 1994, 13, $25-58$. [CrossRef]

45. Scheller, H.V.; Ulvskov, P. Hemicelluloses. Annu. Rev. Plant Biol. 2010, 61, 263-289. [CrossRef] [PubMed]

46. Pérez, J.; Munoz-Dorado, J.; De la Rubia, T.; Martinez, J. Biodegradation and biological treatments of cellulose, hemicellulose and lignin: An overview. Int. Microbiol. 2002, 5, 53-63. [CrossRef]

47. Allred, P.M. Leaf Litter Decomposition Studies in a Blackwater Stream. Ph.D. Thesis, Emory University, Atlanta, GA, USA, 1982.

48. Briones, M.; Ineson, P. Decomposition of eucalyptus leaves in litter mixtures. Soil Biol. Biochem. 1996, 28, 1381-1388. [CrossRef]

49. Ingersoll, T.L.; Baker, L.A. Nitratfe removal in wetland microcosms. Water Res. 1998, 32, 677-684. [CrossRef]

50. Howard-Williams, C.; Davies, B.R. The rates of dry matter and nutrient loss from decomposing Potamogeton pectinatus in a brackish south-temperate coastal lake. Freshw. Biol. 1979, 9, 13-21. [CrossRef]

51. Chen, W.; Westerhoff, P.; Leenheer, J.A.; Booksh, K. Fluorescence excitation-Emission matrix regional integration to quantify spectra for dissolved organic matter. Environ. Sci. Technol. 2003, 37, 5701-5710. [CrossRef]

52. Coble, P.G. Characterization of marine and terrestrial DOM in seawater using excitation-emission matrix spectroscopy. Mar. Chem. 1996, 51, 325-346. [CrossRef]

53. Baker, A. Fluorescence excitation-Emission matrix characterization of some sewage-impacted rivers. Environ. Sci. Technol. 2001, 35, 948-953. [CrossRef]

54. Baker, A.; Inverarity, R. Protein-like fluorescence intensity as a possible tool for determining river water quality. Hydrol. Process. 2004, 18, 2927-2945. [CrossRef] 
55. Bridgeman, J.; Bieroza, M.; Baker, A. The application of fluorescence spectroscopy to organic matter characterisation in drinking water treatment. Rev. Environ. Sci. Bio/Technol. 2011, 10, 277. [CrossRef]

56. Mobed, J.J.; Hemmingsen, S.L.; Autry, J.L.; McGown, L.B. Fluorescence characterization of IHSS humic substances: Total luminescence spectra with absorbance correction. Environ. Sci. Technol. 1996, 30, 3061-3065. [CrossRef]

57. Marhuenda-Egea, F.; Martínez-Sabater, E.; Jordá, J.; Moral, R.; Bustamante, M.; Paredes, C.; Pérez-Murcia, M. Dissolved organic matter fractions formed during composting of winery and distillery residues: Evaluation of the process by fluorescence excitation-emission matrix. Chemosphere 2007, 68, 301-309. [CrossRef] [PubMed]

58. Kim, E.; Bae, J. Alkalinity requirements and the possibility of simultaneous heterotrophicdenitrification during sulfur-utilizing autotrophic denitrification. Water Sci. Technol. 2000, 42, 233-238. [CrossRef]

59. Kim, I.; Son, J. Impact of COD/N/S ratio on dentrification by the mixed cultures of sulfatereducing bacteria and sulfur denitrifying bacteria. Water Sci. Technol. 2000, 42, 69-76. [CrossRef]

60. Lee, D.-U.; Lee, I.-S.; Choi, Y.-D.; Bae, J.-H. Effects of external carbon source and empty bed contact time on simultaneous heterotrophic and sulfur-utilizing autotrophic denitrification. Process Biochem. 2001, 36, 1215-1224. [CrossRef]

61. Chen, C.; Ren, N.; Wang, A.; Liu, L.; Lee, D.-J. Functional consortium for denitrifying sulfide removal process. Appl. Microbiol. Biotechnol. 2010, 86, 353-358. [CrossRef]

62. Pu, J.; Feng, C.; Liu, Y.; Li, R.; Kong, Z.; Chen, N.; Tong, S.; Hao, C.; Liu, Y. Pyrite-based autotrophic denitrification for remediation of nitrate contaminated groundwater. Bioresour. Technol. 2014, 173, 117-123. [CrossRef]

63. Hoorens, B.; Aerts, R.; Stroetenga, M. Does initial litter chemistry explain litter mixture effects on decomposition? Oecologia 2003, 137, 578-586. [CrossRef]

64. Villar, C.A.; De Cabo, L.; Vaithiyanathan, P.; Bonetto, C. Litter decomposition of emergent macrophytes in a floodplain marsh of the Lower Paraná River. Aquat. Bot. 2001, 70, 105-116. [CrossRef]

65. Birgand, F.; Skaggs, R.W.; Chescheir, G.M.; Gilliam, J.W. Nitrogen removal in streams of agricultural catchments-A literature review. Crit. Rev. Environ. Sci. Technol. 2007, 37, 381-487. [CrossRef]

66. Yatong, $\mathrm{X}$. The influence of $\mathrm{pH}$ values and temperature on denitrification. China Environ. Sci. 1994, 14, 308-313.

67. Knowles, R. Denitrification. Microbiol. Rev. 1982, 46, 43. [CrossRef] [PubMed]

68. Lee, K.-C.; Rittmann, B.E. Effects of $\mathrm{pH}$ and precipitation on autohydrogenotrophic denitrification using the hollow-fiber membrane-biofilm reactor. Water Res. 2003, 37, 1551-1556. [CrossRef]

69. Chen, Y.; Wen, Y.; Zhou, Q.; Vymazal, J. Effects of plant biomass on denitrifying genes in subsurface-flow constructed wetlands. Bioresour. Technol. 2014, 157, 341-345. [CrossRef]

70. García-Lledó, A.; Vilar-Sanz, A.; Trias, R.; Hallin, S.; Bañeras, L. Genetic potential for $\mathrm{N}_{2} \mathrm{O}$ emissions from the sediment of a free water surface constructed wetland. Water Res. 2011, 45, 5621-5632. [CrossRef]

71. Jones, C.M.; Stres, B.; Rosenquist, M.; Hallin, S. Phylogenetic analysis of nitrite, nitric oxide, and nitrous oxide respiratory enzymes reveal a complex evolutionary history for denitrification. Mol. Biol. Evol. 2008, 25, 1955-1966. [CrossRef] [PubMed]

72. Della Rocca, C.; Belgiorno, V.; Meriç, S. An heterotrophic/autotrophic denitrification (HAD) approach for nitrate removal from drinking water. Process Biochem. 2006, 41, 1022-1028. [CrossRef]

73. Oh, S.; Bum, M.; Yoo, Y.; Zubair, A.; Kim, I. Nitrate removal by simultaneous sulfur utilizing autotrophic and heterotrophic denitrification under different organics and alkalinity conditions: Batch experiments. Water Sci. Technol. 2003, 47, 237-244. [CrossRef]

74. Reyes-Avila, J.; Razo-Flores, E.A.; Gomez, J. Simultaneous biological removal of nitrogen, carbon and sulfur by denitrification. Water Res. 2004, 38, 3313-3321. [CrossRef]

75. Chen, C.; Ho, K.-L.; Liu, F.-C.; Ho, M.; Wang, A.; Ren, N.; Lee, D.-J. Autotrophic and heterotrophic denitrification by a newly isolated strain Pseudomonas sp. C27. Bioresour. Technol. 2013, 145, 351-356. [CrossRef]

76. Peirano, C.; Guerrero, L.; Barahona, A.; Montalvo, S.; Huiliñir, C.; Da Silva, C.; Borja, R. Assessment of simultaneous autotrophic-Heterotrophic denitrification with high removal of nitrogen, sulfur and carbon: Optimization through response surface methodology. J. Chem. Technol. Biotechnol. 2019, 95, 631-638. [CrossRef]

(C) 2020 by the authors. Licensee MDPI, Basel, Switzerland. This article is an open access article distributed under the terms and conditions of the Creative Commons Attribution (CC BY) license (http://creativecommons.org/licenses/by/4.0/). 